\title{
FUNGITOXICITY OF ESSENTIAL OILS ON Plasmopara viticola,CAUSAL AGENT OF GRAPEVINE DOWNY MILDEW ${ }^{1}$
}

\author{
RÉGIS DE OLIVEIRA FIALHO ${ }^{2}$, MARLI DE FÁTIMA STRADIOTO PAPA ${ }^{3}$, \\ ALAN RODRIGO PANOSSO ${ }^{4}$, ANA MARIA RODRIGUES CASSIOLATO ${ }^{5}$
}

\begin{abstract}
This study aimed to evaluate the fungitoxic (antifungal) effect of seven essential oils on Plasmopara viticola, the causal agent of grapevine downy mildew. The cinnamon, eucalyptus globulus, marjoram, melaleuca, peppermint, oregano and white thyme essential oils were compared with the mancozeb + metalaxyl-M fungicide. Three experiments were conducted to evaluate the effect of essential oils on spore germination. The first experiment evaluated the effect of direct contact of essential oils on the pathogen; the second evaluated the effect of volatile compounds on the pathogen and the third assessed the behavior of essential oils, when applied to vine leaves in field conditions, on the pathogen. All essential oils inhibited the spores' germination, but in varying degrees, in addition, presenting fungistatic activity. All the essential oils showed chemical instability when the incubation time or the interval between products application where increased, all oils decrease antifungal activity percentage. Noteworthy, the cinnamon and the eucalyptus globulus essential oils were the most fungitoxic (antifungal) on P. viticola.
\end{abstract}

Index terms: Fungicidal activity, fungistatic activity, alternative control, spore germination.

\section{FUNGITOXICIDADE DE ÓLEOS ESSENCIAIS SOBRE Plasmopara viticola, AGENTE CAUSAL DO MÍLDIO DA VIDEIRA}

RESUMO - O estudo teve como objetivo avaliar o efeito antifúngico de sete óleos essenciais sobre a germinação de esporos de Plasmopara viticola, agente causal do míldio da videira. Os óleos essenciais de canela, eucalipto globulus, manjerona, melaleuca, peppermint, orégano e tomilho branco foram comparados com o fungicida mancozebe + metalaxil-M. Foram realizados três experimentos avaliando o efeito dos óleos essenciais na germinação de esporos. O primeiro experimento avaliou o efeito do contato direto dos óleos essenciais sobre o patógeno; o segundo avaliou o efeito dos compostos voláteis sobre o patógeno e o terceiro avaliou o comportamento dos óleos essenciais, quando aplicados em folhas de videira em condições de campo, sobre o patógeno. Todos os óleos essenciais inibiram a germinação dos esporos de $P$. viticola, mas em graus variáveis, além de apresentarem atividade fungistática. Todos os óleos essenciais possuem instabilidade química, visto que, à medida que se aumenta o tempo de incubação ou o intervalo entre a aplicação dos produtos, a percentagem de atividade antifúngica de todos os óleos diminui. Nos menores períodos de incubação, mas em altas concentrações, os óleos essenciais são tão eficientes quanto o fungicida. Destacam-se os óleos essenciais de canela e eucalipto globulus como os mais antifúngicos sobre $P$. viticola. Termos de indexação: Atividade fungicida, atividade fungistática, controle alternativo, germinação de esporos.

\footnotetext{
1(Paper 239-15). Received October 20, 2015. Accepted August 12, 2016.

${ }^{2}$ Engo. Agro., Mestrando em Agronomia, bolsista FAPESP, UNESP, Câmpus de Ilha Solteira - SP, E-mail: regis.fialho12@gmail.com ${ }^{3}$ Enga .Agra ., Dra., profa. do Departamento de Fitossanidade, Engenharia Rural e Solos/UNESP, Câmpus de Ilha Solteira -SP, E-mail: marlifsp@agr.feis.unesp.br

${ }^{4}$ Engo. Agro., Dr., prof. do Departamento de Matemática/UNESP, Câmpus de Ilha Solteira -SP, E-mail: arpanosso@yahoo.com.br ${ }^{5}$ Bióloga, Dra., profa. do Departamento de Fitossanidade, Engenharia Rural e Solos/UNESP, Câmpus de Ilha Solteira -SP, E-mail: anamaria@agr.feis.unesp.br
} 


\section{INTRODUCTION}

The grapevine (Vitis spp.) is economically one of the most important fruits cultivated in the world, because of the diverse uses of its fruits. It is present in more than 90 countries and in Brazil it occupies the twelfth place in planted area (ha) among the fruits (Food and Agriculture Organization). The production of grapes in Brazil in 2013 was 1,439.5 thousand tons, in a harvested area of 79.1 thousand hectares (IBGE, 2014).

A number of factors, including diseases, can influence the grapevine productivity. The most important for the crop is downy mildew caused by Oomyceto Plasmopara viticola (Berk. \& Curtis) Berl. \& Toni. Due to its biotrophic characteristic, it can infect all the green tissues, reducing the photosynthetic area and blocking the translocation of assimilates, from its source of production to the growth areas and fruits, causing the plant death (AZIZ et al., 2006). Under favorable climatic conditions, and when control measures are not applied, downy mildew can reduce fruit yield up to 70\% (GARRIDO; ANGELOTTI, 2011).

The downy mildew control carries out in a similar way in all producing regions, with weekly applications of fungicides, increasing production costs, risks of workers intoxication and environment contamination (NAVES et al., 2006). Although chemical control has contributed for several years to economic viability and efficiency in disease control in crop, there is a growing concern about environmental damage, consumer health and resistance development due to the repeated use of synthetic compounds (TRIPATHI et al., 2008).

In the search for new alternatives for the control of plant diseases, secondary plant metabolism compounds present in essential oils with antifungal potential may be a viable option in the management of plant diseases in pre-and postharvest (CHAGAS et al., 2014; MAIA et al., 2014). In the worldwide literature, there is a significant increase in the number of studies that seek to find antifungal activity of essential oils as an alternative control of several plant pathogens, with promising results for cinnamon (RANASINGHE et al., 2002; KISHORE et al., 2007; MAQBOOL et al., 2010), eucalyptus (LORENZETTI et al., 2012), marjoram (FIALHO, 2012), melaleuca (FRASSON et al.,2010), peppermint (CHAGAS et al., 2014) oregano (MALLET et al., 2014) and white thyme oils (PERINA et al., 2015). Aiming at to contribute to one more option to control the downy mildew of the grapevine, the objective of this study was to evaluate the antifungal effect of essential oils on the spore germination of $P$. viticola, a causal agent of grapevine downy mildew.

\section{MATERIALS AND METHODS}

Three experiments were carried out at the Laboratory of Plant Diseases of the University of Engineering, UNESP - São Paulo State University, Ilha Solteira Campus and in a private vineyard located in the Green Belt, in the municipality of Ilha Solteira/SP. Selected based on results from previous experiments (FIALHO, 2012) and purchased from the Ferquima Ind. and Com. Ltda. Company (Vargem Grande Paulista-SP), the essential oils were obtained from leaves of cinnamon (Cinnamomum zeylanicum Blume), eucalyptus (Eucalyptus globulus Labill), marjoram (Origanum majorana L.), melaleuca (Melaleuca alternifolia Cheel), peppermint (Mentha piperita L.) and oregano (Origanum vulgare L.) and from flower and leaves of white thyme (Thymus vulgaris L.) plant.

Following the recommendation of Agrofit (2015), these essential oils were compared with a chemical control, the commercial product Ridomil Gold MZ, a fungicide specific for downy mildew control. This product is consisted of the mancozeb + metalaxyl-M mixture, at $640+40 \mathrm{~g}$ a.i. $\mathrm{kg}^{-1}$ of c.p. and recommended at the dose of $2.5 \mathrm{~g}$ of c.p. $\mathrm{L}^{-1}$ of water, which corresponds, respectively, to 1.6 +0.1 of a.i. $L^{-1}$. To guarantee the perfect mixing of essential oils or fungicide plus water was used Tween 80 detergent $(0.5 \%)$

To prepare the spore suspensions of $P$. viticola, as used in the three conducted experiments, leaves of grapevines with symptoms of downy mildew, were collected in the field and packed in plastic bag. Those leaves were kept in a polystyrene box until its handling in the laboratory. The spores, with the help of a brush, were transferred to a beaker containing $10 \mathrm{~mL}$ of sterilized deionized water. The spore suspensions were filtered through double gauze and the concentration were adjusted to $2 \mathrm{x}$ $10^{4}$ spores $\mathrm{mL}^{-1}$.

Disruption of spore germination, when necessary, carried out by deposition of one drop of lactoglycerol on the spore suspension, per Petri dish. The evaluation of spore germination, under optical microscopy, only considered those that had the zoospores release and emptiness appearance. After determining the percentage of spore germination, using 100 spores per replication, it was possible to calculate the percentage of spore germination inhibition (PGI) of each treatment, in relation to the 
chemical control treatment.

Evaluation of the direct contact of the essential oils on the spore germination of P. viticola

The effect of the direct contact time and oils concentrations on the spore germination of $P$. viticola were evaluated by adding essential oil or fungicidal plus Tween 80 at $0.5 \%$ to the still-fused agar-water (AW) culture medium. The essential oils were used at concentrations of $0.1 ; 0.5 ; 1 ; 2$ and $4 \%$ and the fungicide at the recommended dose for field application (AGROFIT, 2015). The control treatment consisted only of AW culture medium plus Tween 80 at $0.5 \%$. On the solidified medium was deposited $80 \mu \mathrm{L}$ of the spore suspension and the Petri dishes were conditioned in the incubator at $25^{\circ} \mathrm{C}$, for 6 , 12,24 and $48 \mathrm{~h}$. At the end of each period, the spore germination were evaluated by interrupting this process. The experimental design was completely randomized, with a factorial arrangement of $7 \times 5$ $\mathrm{x} 4+1$ (essential oils $\mathrm{x}$ concentrations $\mathrm{x}$ incubation periods + fungicide (additional treatment)), with five replicates, consisting of one Petri dish each.

\section{Evaluation of volatile compounds of} essential oils on the spore germination of $P$. viticola

The effect of the volatile compounds of the essential oils on the germination of $P$. viticola were evaluated by soaking qualitative filter paper disks, with four centimeters in diameter, on essential oils or fungicide solution. The disks were placed under the lid, on the inner surface of the Petri dish $(90 \mathrm{x}$ $15 \mathrm{~mm}$ ), according to the modified methodology of Ootani (2010), and $95 \mathrm{~mL}$ of air was used as the standard value for each Petri dish. The concentrations of essential oils of $0.1 ; 0.5 ; 1 ; 2$ and $4 \%$ were expressed as volume of volatile compounds in filter paper, by volume of Petri dish, converted to $0.095 ; 0.475 ; 0.95 ; 1.9$ and $3.8 \mathrm{~mL} \mathrm{~mL}^{-1}$ of air. The concentration of the Ridomil Gold MZ fungicide of $2.5 \mathrm{~g}$ of c.p. $\mathrm{L}^{-1}$ water was expressed as commercial product grams on filter paper, by volume of Petri dish, and converted to $0.0025 \mathrm{~g}$ of c.p. $\mathrm{mL}^{-1}$ of air. Thus, $0.24 \mathrm{~g}$ of c.p. was used for each repetition. For the control treatments, the filter paper was only moistened with deionized and sterilized water.

On the AW culture medium, $80 \mu \mathrm{L}$ of the spore suspension were deposited. The Petri dishes were wrapped with plastic film, with the lid facing down, and placed at $25^{\circ} \mathrm{C}$, in an incubator. For each treatment, five replicates, consisting of one Petri dish each, were used. Thus, five plants were evaluated after $24 \mathrm{~h}$ of incubation. The lids of the remaining five Petri dishes from each treatment were exchanged for fresh lids, without the filter paper. After being sealed again with plastic film, they were incubated at $25^{\circ} \mathrm{C}$. The second evaluation of spore germination was performed $48 \mathrm{~h}$ after the initial incubation. The exchange of Petri dish lids occurred in order to evaluate the existence of fungistatic activity of the oils on spore germination, with 24 and 48 h of incubation.

The experimental design was completely randomized, with a factorial arrangement of $7 \times 5$ $\mathrm{x} 2+1$ (essential oils $\mathrm{x}$ concentrations $\mathrm{x}$ incubation periods + fungicide (additional treatment)), with five replicates, consisting of one Petri dish each. With the data, the percentage of spores' germination inhibition (PGI) was calculated after 24 and $48 \mathrm{~h}$ of incubation. The fungistatic activity of the essential oils was considered the difference between the percentages of spore germination inhibition between the two incubation periods. If there is a fungistatic activity of the essential oils, the spore PGI will be higher in the evaluation after $24 \mathrm{~h}$ and lower after $48 \mathrm{~h}$ of incubation, that is, initially the spores may not germinate but they germinate later without the presence of the volatile compounds.

\section{Evaluation of essential oils in the spore germination of $P$. viticola, applied on grapevine leaves under field conditions}

This experiment was carried out on a private property, in a vineyard area of the Niagara White variety, conducted on an espalier, with spacing of $1.0 \times 2.0 \mathrm{~m}$. As the property's grapevine plants were not pruned and did not receive chemical treatment throughout the crop cycle, there was a natural occurrence of downy mildew. For each treatment, four grapevine sprouts with six to eight leaves were identified, which showed, visually, recent sporulation of $P$. viticola.

For the application of the essential oils in the grapevine leaves in the field, the average concentration of the oils evaluated under laboratory conditions was used. These were prepared at $1 \%$ and the fungicide was at the recommended dose for field application (AGROFIT, 2015). For the control treatment, deionized water was applied. In all treatments, Tween 80 at $0.5 \%$ and the formulated preparations were applied with the aid of a hand sprayer, equipped with the full cone type nozzle. During the application, a transparent plastic bag was used to wrap the branch and to avoid the drift of the products in the neighboring branches. The application was only carried out on the identified grapevine sprouts, which was done before 9 o'clock in the morning, until the point of run-off. 
After 24 and $48 \mathrm{~h}$ of the application, two leaves of each sprout were collected from each replicate, totaling eight leaves per treatment. From these, spore suspensions were prepared for each treatment so that the viability of $P$. viticola spores could be compared after 24 and $48 \mathrm{~h}$ of the products application. On the solidified AW culture medium, $80 \mu \mathrm{L}$ of the spore suspension were deposited. These dishes were housed in an incubator at $25^{\circ} \mathrm{C}$ for $12 \mathrm{~h}$. After this period, the germination process was interrupted to carry out the spore germination evaluations. The experimental design was completely randomized, with a factorial arrangement of $7 \times 1 \times$ $2+2$ (essential oils $\mathrm{x}$ concentrations $\mathrm{x}$ incubation periods + control + fungicide (additional treatment)), with five replicates, consisting of one Petri dish each.

\section{Statistical Analysis}

The data were submitted to the variance and regression analyses. In the qualitative factor (essential oils), the averages were compared by the Skott-Knott test at $5 \%$ probability, and for the quantitative factors (time and concentrations) regression equations were adjusted based on the " $F$ " test of the coefficients at $5 \%$ probability and in the coefficient of determination $\left(\mathrm{R}^{2}\right)$. The Dunnett test at $1 \%$ probability was carried out to compare the PGIs obtained in each essential oil and with the PGIs of the additional treatment (fungicide). All analyzes were carried out using the $\mathrm{R}$ statistical program (R DEVELOPMENT CORE TEAM, 2011). To determine the most efficient essential oil in direct contact or volatile compounds with the pathogen, in each evaluation period, the $\mathrm{CL}_{50}$ of the essential oils were calculated from the regression equations adjusted for each period or their average, when the interactions between the sources of variation were not significant.

\section{RESULTS AND DISCUSSION}

\section{Effect of the direct contact of the essential} oils on the spore germination of $P$. viticola

In direct contact of the essential oils on the PGI of $P$. viticola spores and disregarding the concentrations, the cinnamon oil showed the highest percentage of germination inhibition (70\%), followed by eucalyptus globulus and marjoram, while the lowest values of PGI were found for white thyme $(43 \%)$ and oregano (Table 1). Different from the oils, there was no reduction in PGI in function of the incubation period for the chemical control (Table 1).

The different behaviors of the essential oils on the pathogen, verified in this study, may be related to their chemical composition. However, in addition to concentrations and genetic traits, other factors are responsible for influencing the chemical composition of essential oils, such as age and stage of plants development; climatic and environmental factors; the part of the plant used; the soil and fertilization, in addition to the distillation and storage conditions (OLADIMEJI et al., 2001; MORAIS, 2009).

The effect of the essential oils in direct contact with the pathogen also varied over the long period of incubation, for inhibition of $50 \%$ of the spore germination $\left(\mathrm{CL}_{50}\right)$. Among the seven essential oils evaluated, cinnamon is the most antifungal on $P$. viticola, and the only one to present when exhibiting $\mathrm{CL}_{50}$ after $12 \mathrm{~h}$ of incubation (Table 1). The basil and melaleuca oil, with PGI of 64 and 59\%, respectively, showed $\mathrm{CL}_{50}$ below $0.1 \%$ after $6 \mathrm{~h}$ of incubation, while oregano and white thyme were again the least efficient in all periods, and peppermint for the two largest incubation periods (Table 1).

These different sensitivities of pathogens to essential oils were also related to the chemical concentration and to the nature of their constituents (CHANG et al., 2001). The aldehydes, when compared to alcohols, provide greater antifungal control, according to Kalemba and Kunicka (2003); for the eucalyptus essential oil, Viturro et al. (2003) found that terpenoid alcohol 1.8-cineol is the main constituent, whereas Koketsu et al. (1997) reported that in cinnamon bark oil, cinnamic aldehyde (55\%) and eugenol $(12 \%)$ are found. Thus, the higher antifungal activity of cinnamon oil may be due to the high aldehyde content in its composition.

The spore PGI of $P$. viticola showed different behaviors in function of the incubation periods $(6$, 12,24 and $48 \mathrm{~h}$ ) $\mathrm{x}$ the concentrations of the essential oils. In the highest concentration (4\%), the highest germination inhibition was observed for all oils, especially cinnamon, eucalyptus, marjoram and melaleuca, which provided $100 \%$ inhibition of $P$. viticola spore germination after $6 \mathrm{~h}$ incubation. At the same concentration and incubation period, all the oils showed the highest PGI above $85 \%$, however, regardless of the concentration used, the lowest PGI occurred with an increase in the incubation period (Figures 1 and 2).

The overall average PGI of the manconzeb + metalxil-M fungicide was $89 \%$, significantly higher than the overall average PGI of all evaluated oils (Table 1). However, the cinnamon essential oils after $6 \mathrm{~h}$ incubation at $1 \%$ concentration and after 12 and $24 \mathrm{~h}$ at $4 \%$; the eucalyptus globulus after 12 and $24 \mathrm{~h}$ at $4 \%$; the marjoram after $6 \mathrm{~h}$ at 0.5 and $1 \%$, and after $12 \mathrm{~h}$ at 2 and $4 \%$; the melaleuca after $6 \mathrm{~h}$ at $0.5 \%$ and after $12 \mathrm{~h}$ at 2 and $4 \%$; the peppermint after $6 \mathrm{~h}$ at 2 
and $4 \%$ and the oregano and white thyme after $6 \mathrm{~h}$ at $4 \%$ concentration did not differ significantly from the fungicide treatment. In addition, the essential oils of cinnamon, eucalyptus, marjoram and melaleuca after $6 \mathrm{~h}$ of incubation at 2 and $4 \%$ were more efficient when compared to the fungicide (Table 2).

The positive results verified in the control of the $P$. viticola spore germination, by the cinnamon essential oil in this study, corroborate the reported by other authors, but for different pathogens. Maqbool et al. (2010) evaluated the inhibition of conidial germination of Colletotrichum musae (Berk. \& Curtis) von Arx, detected significant inhibition at the concentration of $0.4 \%$, while Lucas (2012) verified $100 \%$ inhibition of Alternaria solani spore germination (Ell. \& Martin) Jones \& Grout, at the concentration of $1000 \mu \mathrm{L} \mathrm{L}^{-1}$.

During the evaluation of PGI by direct contact of the essential oils, we detected that the oils killed part of the pathogen spores, and that the other part remained without germinating, due to the fungistatic action. That is, in the incubation longer periods, due to luminosity, heat, oxygen and humidity, the oils must have been degraded, allowing the germination of dormant spores. For Simões and Spitzer (2004), when the oils are exposed for longer period under environmental conditions, they become very unstable, suffering numerous reactions of chemical decomposition, losing their quality due to the concentration decrease of main components.

\section{Effect of volatile compounds of essential oils on the spore germination of $P$. viticola}

As for the volatile compounds of the essential oils, spore PGI varied and showed the interaction of concentrations within the incubation periods (Figure 3 ). For cinnamon (Figure 3A), eucalyptus globulus (Figure 3B) and melaleuca oils (Figure 3C), the regression curves were determined from the average of the two incubation periods, while the interactions between the variation sources were not significant. For the other oils, there were interaction between the incubation periods and the concentrations, and the regression curves were determined for each incubation period, evidencing the differentiated behavior of the concentrations within each period. All the essential oils showed a quadratic positive adjustment for the concentrations.

Regardless of the incubation period, for all essential oils, the PGI values were higher with the increased concentrations. After $24 \mathrm{~h}$ of incubation, marjoram, peppermint, oregano and white thyme provided the highest spore PGI values, but with the increase in incubation time for $48 \mathrm{~h}$, all oils showed a reduction in these values (Figure 3). This reduction of spore PGI throughout the incubation period can be considered fungistatic. No studies were found evaluating the fungistatic activity of the essential oils studied on P. vticola. However, Silva et al. $(2012,2014)$ found higher antifungal activity of cinnamon aqueous extract on $P$. viticola spores in the shortest incubation period, but as the incubation period increased, the spore PGI reduced. The authors attributed this higher fungistatic activity to the loss of the antifungal properties of the extracts, due to the longer incubation period. Leite et al. (2011) also reported fungistatic activity of garlic extract and vegetable oil in the control of grapevine downy mildew and germination of sporangia of $P$. viticola causative agent.

After $48 \mathrm{~h}$ of incubation, the highest PGIs for spores kept in contact with volatile compounds, cinnamon and eucalyptus globulus oils showed the lowest ones (Table 3). For this same incubation period, as incubation periods increase, $\mathrm{CL}_{50}$ also increased, indicating the need for a higher oil concentration to inhibit $50 \%$ of spore germination. The efficiency of these products depends on the time of spores' exposure to the product active principle (BANIHASHEMI; ABIVARDI, 2011). After analysis by scanning electron microscopy in samples treated with lemon grass and citronella oils on A. solani, Lucas (2012) found that they delayed the germination process of the conidia, acting as fungistatics, and not fungicide, as was believed.

The spore PGI $(75 \%)$ for manconzeb + metalxyl-M, regardless of the incubation time, exhibited a higher overall average for all evaluated oils. However, the cinnamon essential oil after 24 and $48 \mathrm{~h}$ of incubation at 2 and $4 \%$ concentration; of melaleuca after 24 hours at 2 and $4 \%$ and after $48 \mathrm{~h}$ at $4 \%$; of eucalyptus globulus after 24 and 48 $\mathrm{h}$ at $4 \%$ and those of marjoram, oregano and white thyme after $24 \mathrm{~h}$ at $4 \%$ concentration did not differ significantly from the fungicide treatment (Table 4).

Considering the contact of the P. viticola spores with the volatile compounds of the essential oils, the eucalyptus globulus stands out as the most efficient in inhibiting spore germination, as it presented $\mathrm{CL}_{50}$ below $1 \%$, while peppermint was the less efficient, and it is not possible to determine the required concentration capable of inhibiting spore germination by $50 \%$ (Table 3 ). Other authors have also confirmed this activity for this oil, as Ootani (2010), who reported this effect on Aspergillus sp., Pyricularia grisea (Cooke) Sacc and Colletroticum musae. Vilela et al. (2009) found the effect of volatile compounds of eucalyptus oil on Aspergillus 
flavus Link and Aspergillus parasiticus Speare from the dose of $500 \mu \mathrm{L}$, with more than $90 \%$ of mycelial inhibition for all fungi. Silva et al. (2013) observed $100 \%$ inhibition of mycelial growth and spore germination of Cercospora coffeicola Berk $\&$ Cook by eucalyptus globulus oil. Piatti et al. (2011) reported that, at a concentration of $0.5 \%$, the eucalyptus globulus essential oil provided inhibition of spore germination of Penicillium sp., significantly higher than the Azoxystrobin fungicide.

Effect of essential oils in the spore germination of $P$. viticola applied on grapevine leaves under field conditions

After the application of the essential oils and fungicide on grapevine leaves, the highest PGIs were found after $24 \mathrm{~h}$ of application for all oils (Table 3 ). Among the essential oils, the most efficient were cinnamon and oregano (both with $65 \%$ PGI), followed by eucalyptus globulus $(57 \%)$, while the less efficient ones were melaleuca and peppermint ( 15 and $17 \%$, respectively). After $24 \mathrm{~h}$ of application, the essential oils of cinnamon and oregano did not differ significantly from the fungicide used (Table 5).
After $48 \mathrm{~h}$ of application of the extracts on the leaves, the cinnamon and eucalyptus globulus oils were again the most efficient, with PGI values very close to those detected in the evaluation of $24 \mathrm{~h}$ (57 and $54 \%$, respectively), as well as the melaleuca and peppermint oils were the least efficient (PGI of 7 and $8 \%$, respectively). The melaleuca, peppermint and white thyme oils exhibited a reduction of about $50 \%$ in PGI values between 24 and $48 \mathrm{~h}$ of incubation. The treatment with the fungicide was the most efficient in the field (PGI of 62\%), both after 24 and $48 \mathrm{~h}$ of application (Table 3 and 5).

The existence of the fungistatic activity of the oils is not an interesting characteristic for a product to be indicated for the control of the downy mildew, since it will require several applications in short intervals of time to be efficient and it could be associated with another product that confers more stability to the action of the essential oil. In view of the results obtained, the essential oils may be an option to control the grapevine downy mildew, as long as its unstable characteristics are further studied, so that it becomes a product for the field conditions.

TABLE 1- Percentage of Plasmopara viticola spore germination inhibition (PGI) by essential oils and the Manconzeb + metalaxyl-M fungicide, after four incubation periods, and lethal concentrations for $50 \%\left(\mathrm{CL}_{50}\right)$ of spore germination inhibition, when it is kept in direct contact with the essential oil. Ilha Solteira, SP, 2013.

\begin{tabular}{lccccc}
\hline \multirow{2}{*}{ Oils } & PGI & \multicolumn{4}{c}{$\mathbf{C L}_{50}$ for the incubation periods ${ }^{\mathbf{1}}$} \\
\cline { 4 - 6 } & $\mathbf{( \% )}$ & $\mathbf{6 ~ h}$ & $\mathbf{1 2} \mathbf{~ h}$ & $\mathbf{2 4} \mathbf{~ h}$ & $\mathbf{4 8} \mathbf{~ h}$ \\
\hline Cinnamon & 70 & & $<0.10^{* *}$ & 0.36 & 0.74 \\
E. globulus & 61 & $0.25^{1}$ & 0.39 & 1.00 & 1.22 \\
Marjoram & 64 & $<0.1^{* *}$ & 0.28 & 0.81 & 1.53 \\
Melaleuca & 59 & $<0.1^{* *}$ & 0.49 & 1.17 & 1.80 \\
Peppermint & 50 & 0.16 & 0.50 & 1.99 & 4.35 \\
Oregano & 45 & 1.01 & 1.57 & 2.61 & 2.80 \\
White thyme & 43 & 0.91 & 1.77 & 2.00 & 2.67 \\
\hline Fungicide & 89 & -- & -- & -- & -- \\
\hline
\end{tabular}

${ }^{1}$ Values estimated from the linear or quadratic regression equation, in $\% ; *$ : significant at $1 \%$, at the lowest evaluated concentration $(0.1 \%)$, PGI of inhibition was greater than $50 \%$.

(E. globulus= Eucalyptus globulus) 


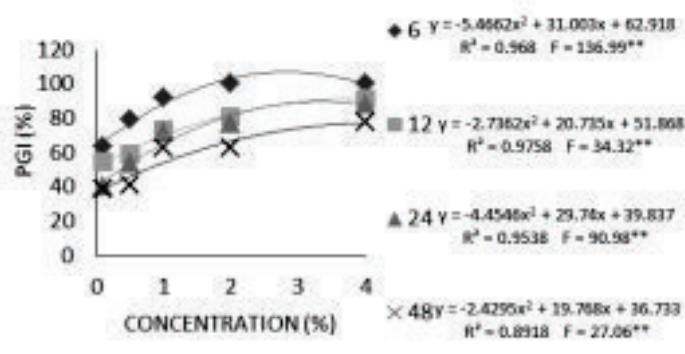

A

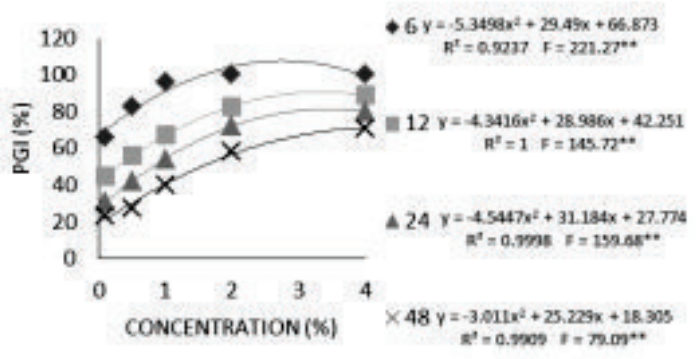

C

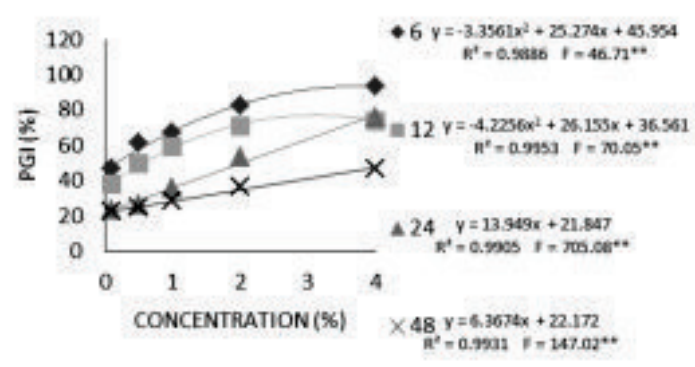

E

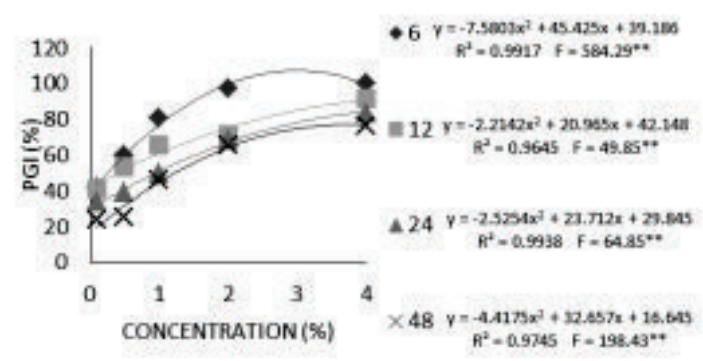

B

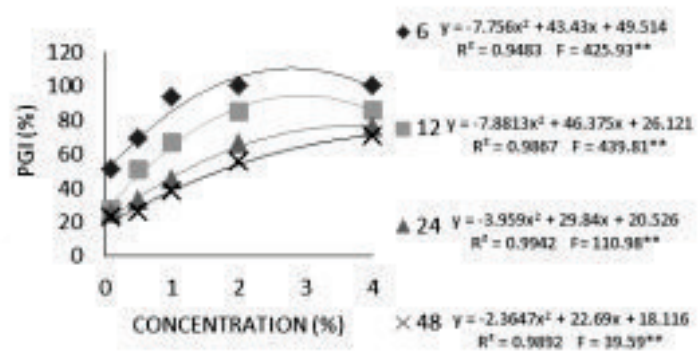

D

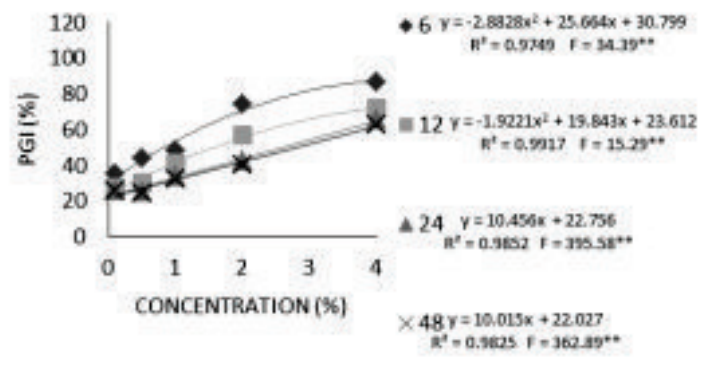

F

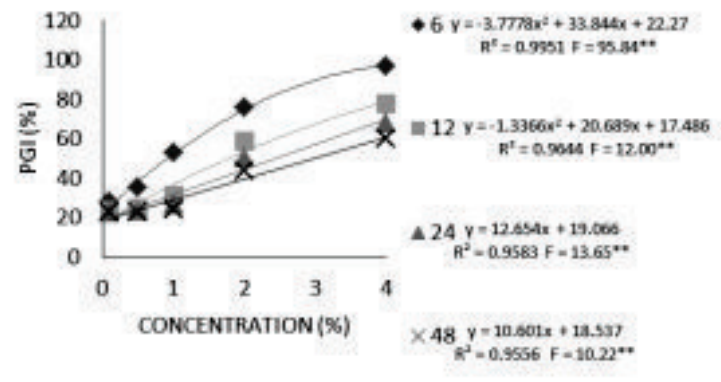

G

FIGURE 1 - Percentage of germination inhibition (PGI) of Plasmopara viticola spores by essential oils of cinnamon (A), eucalyptus globulus (B), marjoram (C), melaleuca (D), peppermint (E), oregano (F) and white thyme $(\mathrm{G})$ at five concentrations $(0.1,0.5,1,2$ and $4 \%)$ for the four incubation periods $\left(6,12,24\right.$ and 48 hours). ( ${ }^{* *}$ : significant at $1 \%$ of probability). 


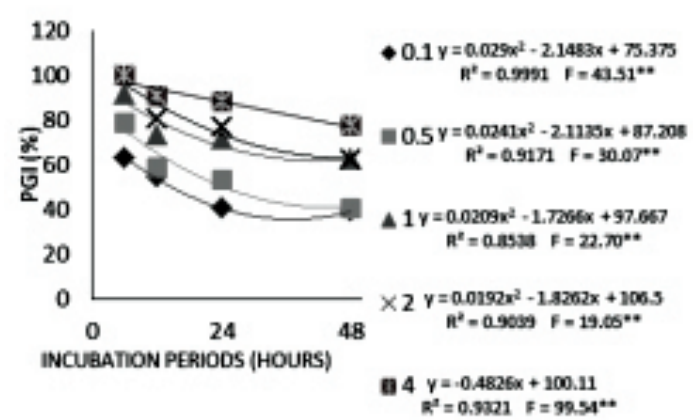

A

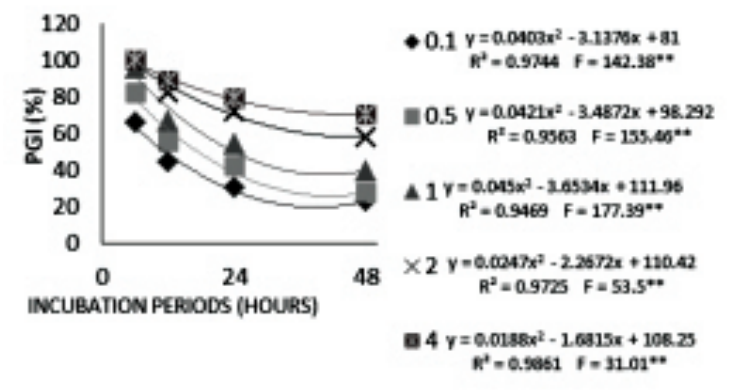

C

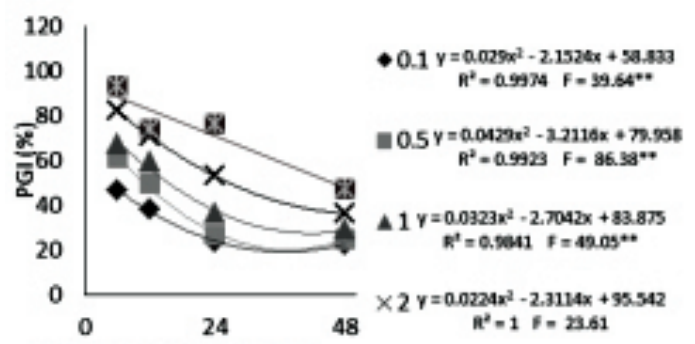

INCUBATION PEROOOS (HOURS)

a $4 y=-0.9703 x+94.457$ $R^{t}=0.8904 \quad F=363.96^{* *}$

E

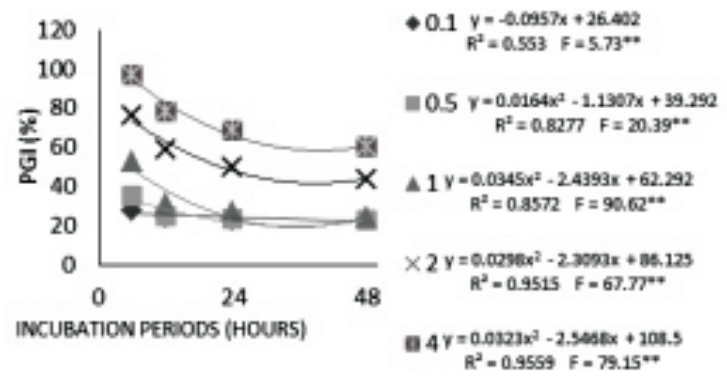

G

B

$R^{2}=0.9559 F=79.15 *+$

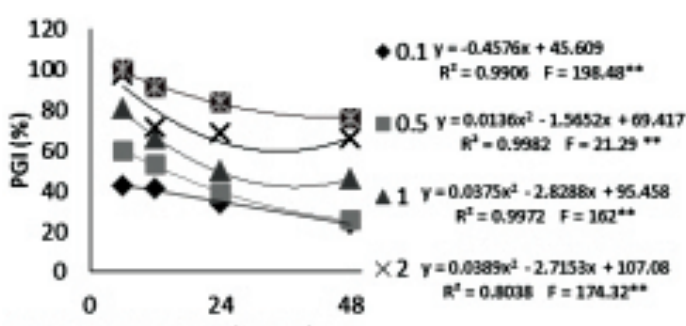

INCUBATION PERIOOS (HOURS) $\quad \mathrm{B} 4 \mathrm{Y}=0.0142 \mathrm{x}^{4}-1.3095 \mathrm{x}+106.46$ $R^{2}=0.987$ F $=23.24^{* *+}$
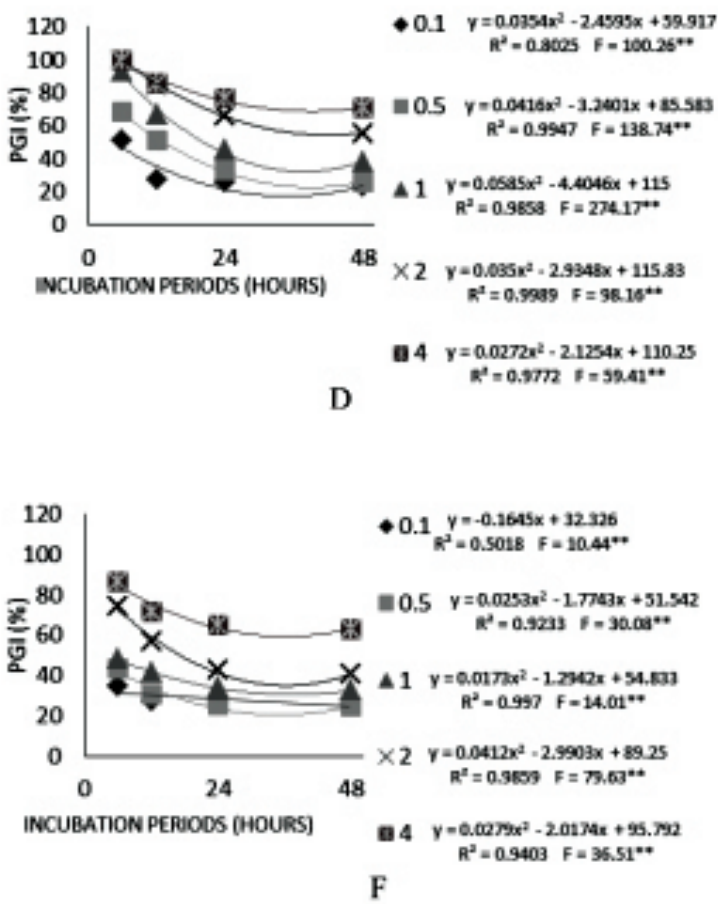

FIGURE 2- Percentage of germination inhibition (PGI) of Plasmopara viticola spores by essential oils of cinnamon (A), eucalyptus globulus (B), marjoram (C), melaleuca (D), peppermint (E), oregano $(F)$ and white thyme $(\mathrm{G})$ for the four incubation periods $(6 ; 12 ; 24$ and 48 hours), at five concentrations $(0.1 ; 0.5 ; 1 ; 2$ and $4 \%) .\left(^{* *}\right.$ : significant at $1 \%$ of probability). 


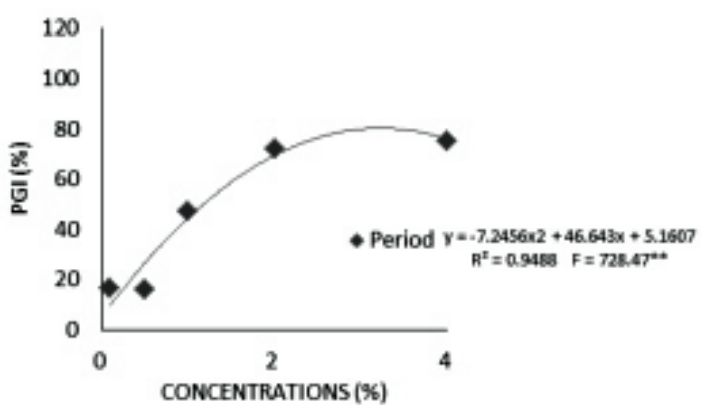

A

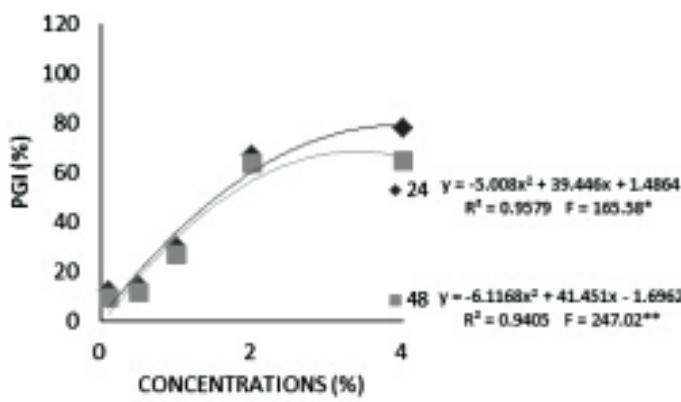

C

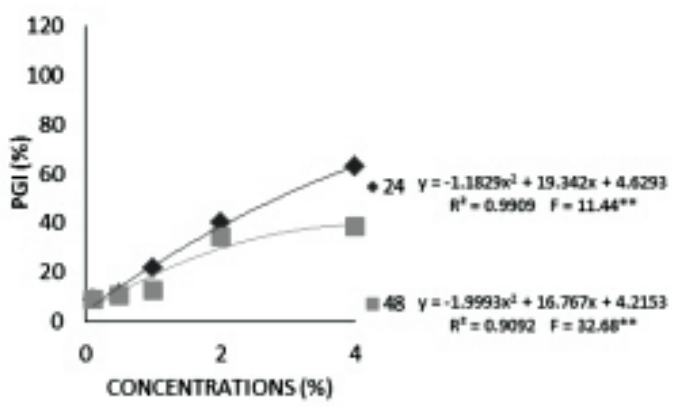

E

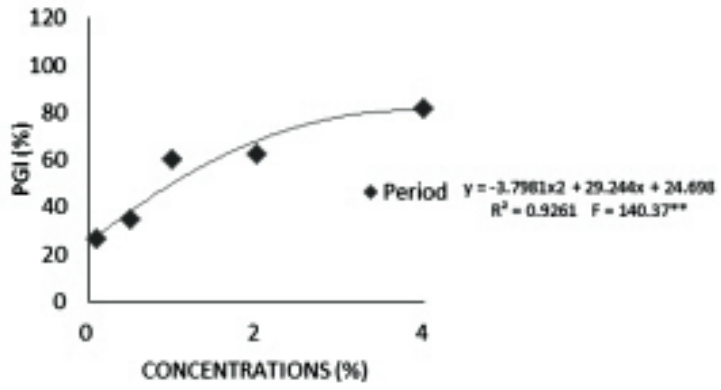

B

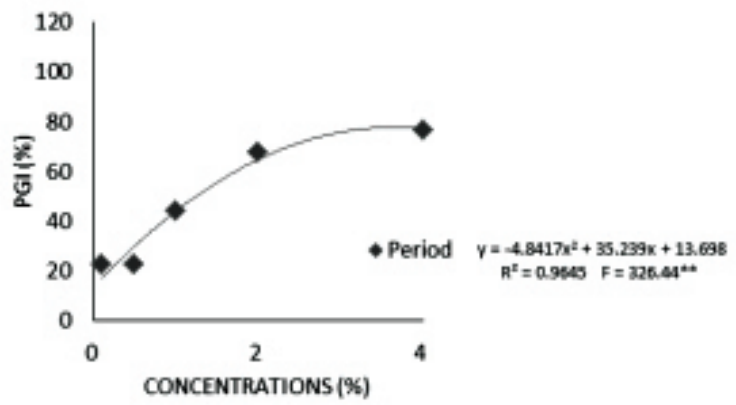

D

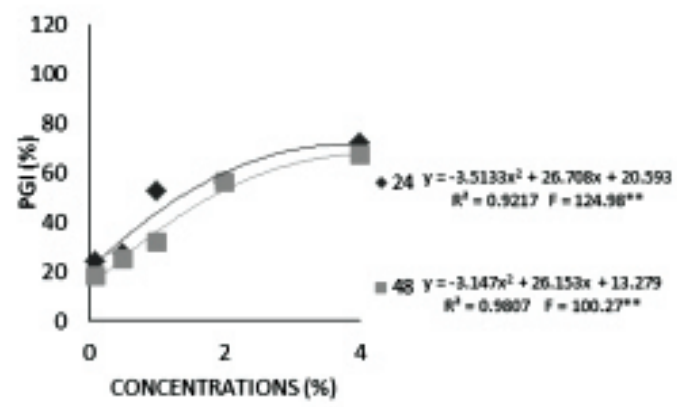

$\mathbf{F}$

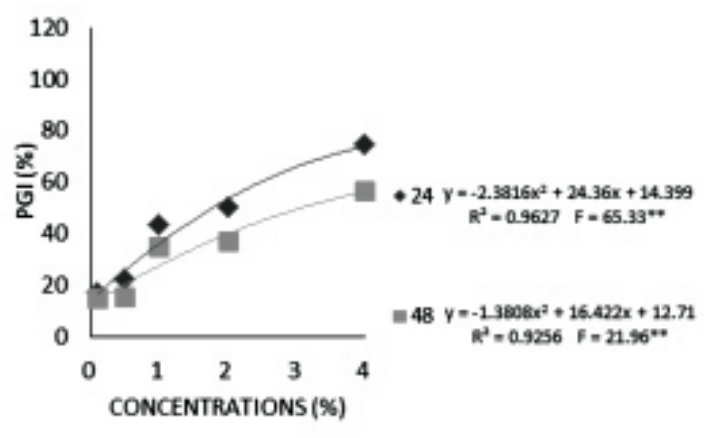

G

FIGURE 3-Effect of volatile compounds of essential oils of cinnamon (A), eucalyptus globulus (B), marjoram (C), melaleuca (D), peppermint (E), oregano (F) and white thyme (G), for percentage of germination inhibition (PGI) of Plasmopara viticola spores, for the two incubation periods (24 and 48 hours), in five concentrations $(0.1,0.5,1,2$ and $4 \%)$. ( ${ }^{* *}$ : significant at $1 \%$ of probability). 
TABLE 2 - Percentage of germination inhibition (PGI) of Plasmopara viticola spores by essential oils and the Manconzeb + metalaxil-M fungicide after four incubation periods when kept in direct contact with the essential oil. Ilha Solteira, SP, 2013.

\begin{tabular}{|c|c|c|c|c|c|c|c|}
\hline \multirow{2}{*}{$\begin{array}{c}\text { Period (h) - } \\
\text { Concentration } \\
(\%)\end{array}$} & \multicolumn{7}{|c|}{ Essential Oils } \\
\hline & Cinnamon & E. globulus & Marjoram & Melaleuca & Peppermint & Oregano & W. thyme \\
\hline $6-0.1$ & $-25.75^{(-)^{1}}$ & $-46.75^{(-)}$ & $-23.00^{(-)}$ & $-38.00^{(-)}$ & $-42.50^{(-)}$ & $-54.00^{(-)}$ & $-60.25^{(-)}$ \\
\hline $6-0.5$ & $-10.00^{(-)}$ & $-29.00^{(-)}$ & $-6.25^{\mathrm{ns}}$ & $-20.25^{(-)}$ & $-28.00^{(-)}$ & $-45.25^{(-)}$ & $-54.00^{(-)}$ \\
\hline $6-1.0$ & $+2.75^{\mathrm{ns}}$ & $-8.50^{(-)}$ & $+7.00^{\mathrm{ns}}$ & $+4.00^{\mathrm{ns}}$ & $-22.00^{(-)}$ & $-41.00^{(-)}$ & $-36.25^{(-)}$ \\
\hline $6-2.0$ & $+11.00^{(+)}$ & $+8.25^{(+)}$ & $+11.00^{(+)}$ & $+11.00^{(+)}$ & $-6.50^{\mathrm{ns}}$ & $-14.75^{(-)}$ & $-13.25^{(-)}$ \\
\hline $6-4.0$ & $+11.00^{(+)}$ & $+11.00^{(+)}$ & $+11.00^{(+)}$ & $+11.00^{(+)}$ & $+4.50^{\mathrm{ns}}$ & $-2.25^{\mathrm{ns}}$ & $+8.00^{\mathrm{ns}}$ \\
\hline $12-0.1$ & $-34.25^{(-)}$ & $-47.75^{(-)}$ & $-44.00^{(-)}$ & $-61.50^{(-)}$ & $-51.00^{(-)}$ & $-61.50^{(-)}$ & $-65.25^{(-)}$ \\
\hline $12-0.5$ & $-30.00^{(-)}$ & $-35.50^{(-)}$ & $-33.25^{(-)}$ & $-38.25^{(-)}$ & $-39.25^{(-)}$ & $-58.50^{(-)}$ & $-64.25^{(-)}$ \\
\hline $12-1.0$ & $-15.50^{(-)}$ & $-23.25^{(-)}$ & $-22.00^{(-)}$ & $-22.50^{(-)}$ & $-29.75^{(-)}$ & $-47.75^{(-)}$ & $-57.75^{(-)}$ \\
\hline $12-2.0$ & $-8.25^{(-)}$ & $-17.75^{(-)}$ & $-6.25^{\mathrm{ns}}$ & $-4.25^{\mathrm{ns}}$ & $-18.00^{(-)}$ & $-32.25^{(-)}$ & $-30.50^{(-)}$ \\
\hline $12-4.0$ & $+2.25^{\mathrm{ns}}$ & $+2.25^{\mathrm{ns}}$ & $-0.25^{\mathrm{ns}}$ & $-3.00^{\mathrm{ns}}$ & $-15.25^{(-)}$ & $-17.00^{(-)}$ & $-11.00^{(-)}$ \\
\hline $24-0.1$ & $-48.75^{(-)}$ & $-55.00^{(-)}$ & $-58.00^{(-)}$ & $-63.75^{(-)}$ & $-65.50^{(-)}$ & $-62.75^{(-)}$ & $-66.00^{(-)}$ \\
\hline $24-0.5$ & $-35.50^{(-)}$ & $-49.75^{(-)}$ & $-46.75^{(-)}$ & $-56.25^{(-)}$ & $-62.50^{(-)}$ & $-63.75^{(-)}$ & $-65.75^{(-)}$ \\
\hline $24-1.0$ & $-17.50^{(-)}$ & $-39.25^{(-)}$ & $-35.00^{(-)}$ & $-44.00^{(-)}$ & $-53.00^{(-)}$ & $-55.00^{(-)}$ & $-62.00^{(-)}$ \\
\hline $24-2.0$ & $-12.00^{(-)}$ & $-20.25^{(-)}$ & $-16.75^{(-)}$ & $-23.00^{(-)}$ & $-36.00^{(-)}$ & $-46.50^{(-)}$ & $-39.00^{(-)}$ \\
\hline $24-4.0$ & $-0.75^{\mathrm{ns}}$ & $-5.00^{\text {ns }}$ & $-9.25^{(-)}$ & $-12.75^{(-)}$ & $-12.75^{(-)}$ & $-27.75^{(-)}$ & $-20.75^{(-)}$ \\
\hline $48-0.1$ & $-50.00^{(-)}$ & $-64.25^{(-)}$ & $-66.00^{(-)}$ & $-66.25^{(-)}$ & $-66.50^{(-)}$ & $-63.25^{(-)}$ & $-66.50^{(-)}$ \\
\hline $48-0.5$ & $-48.25^{(-)}$ & $-63.25^{(-)}$ & $-66.25^{(-)}$ & $-63.25^{(-)}$ & $-64.25^{(-)}$ & $-64.50^{(-)}$ & $-66.50^{(-)}$ \\
\hline $48-1.0$ & $-26.50^{(-)}$ & $-43.00^{(-)}$ & $-49.25^{(-)}$ & $-51.00^{(-)}$ & $-60.25^{(-)}$ & $-56.50^{(-)}$ & $-64.75^{(-)}$ \\
\hline $48-2.0$ & $-26.50^{(-)}$ & $-23.25^{(-)}$ & $-30.75^{(-)}$ & $-33.50^{(-)}$ & $-52.75^{(-)}$ & $-48.50^{(-)}$ & $-45.25^{(-)}$ \\
\hline $48-4.0$ & $-11.50^{(-)}$ & $-12.75^{(-)}$ & $-18.25^{(-)}$ & $-18.25^{(-)}$ & $-42.00^{(-)}$ & $-26.00^{(-)}$ & $-28.75^{(-)}$ \\
\hline Fungicide & & & & 89 & & & \\
\hline $\mathrm{CV}(\%)$ & 4.5 & 3.5 & 3.8 & 4.3 & 6.6 & 7.5 & 6.0 \\
\hline
\end{tabular}

$\mathrm{CV}(\%)=$ coefficient of variation.

$1=$ Average differences of the essential oils with the fungicide.

Averages followed by ${ }^{(-)}$or ${ }^{(+)}$in the column were lower or higher, respectively, to the fungicide, at a $1 \%$ probability level by the Dunnett test;

ns $=$ averages do not differ from the fungicide at the $1 \%$ probability level by the Dunnett test.

(E. globulus= Eucalyptus globulus. W. thyme= White thyme). 
TABLE 3- Average percentage of spore germination inhibition (PGI) of Plasmopara viticola and its lethal concentration on $50 \%$ inhibition $\left(\mathrm{CL}_{50}\right)$, in two incubation periods ( 24 and 48 hours), when spores were kept in contact with volatile compounds of the essential oils and the Manconzeb + metalaxyl-M fungicide; and PGI of spores after two incubation periods ( 24 and 48 hours) when the essential oils and fungicide were applied to the grapevine leaves under field conditions. Ilha Solteira, SP, 2013.

\begin{tabular}{|c|c|c|c|c|c|}
\hline \multirow[t]{2}{*}{ Oils } & \multirow{2}{*}{$\begin{array}{l}\text { PGI } \\
(\%) \\
\end{array}$} & \multicolumn{2}{|c|}{$\begin{array}{l}\mathrm{CL}_{50} \text { for the } \\
\text { incubation periods }\end{array}$} & \multicolumn{2}{|c|}{$\begin{array}{l}\text { PGI }(\%) \text { after the } \\
\text { applications, in field }\end{array}$} \\
\hline & & $24 \mathrm{~h}$ & $48 \mathrm{~h}$ & $24 \mathrm{~h}$ & $48 \mathrm{~h}$ \\
\hline Cinnamon & 45 & \multicolumn{2}{|c|}{$1.17^{2}$} & $65 \mathrm{aA}^{4}$ & $57 \mathrm{bA}$ \\
\hline E. globulus & 53 & \multicolumn{2}{|c|}{$0.96^{2}$} & $57 \mathrm{aB}$ & $54 \mathrm{bB}$ \\
\hline Marjoram & 38 & 1.50 & 1.52 & $43 \mathrm{aC}$ & $35 \mathrm{bC}$ \\
\hline Melaleuca & 47 & \multicolumn{2}{|c|}{$1.21^{2}$} & $15 \mathrm{aD}$ & $7 \mathrm{bE}$ \\
\hline Peppermint & 25 & 2.82 & $\mathrm{ND}^{3}$ & $17 \mathrm{aD}$ & $8 \mathrm{bE}$ \\
\hline Oregano & 43 & 0.90 & 1.77 & $65 \mathrm{aA}$ & $37 \mathrm{bC}$ \\
\hline W. thyme & 37 & 2.00 & 3.10 & $42 \mathrm{aC}$ & $21 \mathrm{bD}$ \\
\hline Fungicide & 75 & -- & -- & 74 & 62 \\
\hline CV (\%) & -- & \multicolumn{2}{|c|}{-- } & \multicolumn{2}{|c|}{5.3} \\
\hline
\end{tabular}

$\mathrm{CV}(\%)=$ coefficient of variation.

${ }^{1}$ Values estimated from the quadratic regression equation, in $\%$; ${ }^{2}$ There was no significant difference between the periods of 24 and 48 hours of incubation; ${ }^{3}$ At no concentration, this essential oil inhibited $50 \%$ of spore germination.

${ }^{4}$ Averages followed by the same letter, lowercase in the line and upper case in the column, do not differ statistically from one another by the Skott-Knott test at $1 \%$ probability.

(E. globulus= Eucalyptus globulus; W. thyme= White thyme).

TABLE 4- Differences between the average percentage of germination inhibition (PGI) of Plasmopara viticola spores, by essential oils and the Manconzeb + metalaxyl-M fungicide, after two incubation periods ( 24 and 48 hours) when kept in contact with volatile compounds of the essential oils and the fungicide. Ilha Solteira, SP, 2013.

\section{Period (h) - $\quad$ Essential Oils}

Concentration (\%) Cinnamon E. globulus Marjoram Melaleuca Peppermint Oregano W. thyme

\begin{tabular}{cccccccc}
\hline $24-0.1$ & $-56.25^{(-)^{1}}$ & $-46.00^{(-)}$ & $-63.00^{(-)}$ & $-49.75^{(-)}$ & $-66.00^{(-)}$ & $-51.00^{(-)}$ & $-58.25^{(-)}$ \\
$24-0.5$ & $-56.75^{(-)}$ & $-39.75^{(-)}$ & $-61.00^{(-)}$ & $-50.00^{(-)}$ & $-64.00^{(-)}$ & $-48.00^{(-)}$ & $-53.00^{(-)}$ \\
$24-1.0$ & $-27.75^{(-)}$ & $-15.00^{(-)}$ & $-45.00^{(-)}$ & $-26.75^{(-)}$ & $-53.00^{(-)}$ & $-22.50^{(-)}$ & $-31.50^{(-)}$ \\
$24-2.0$ & $-3.75^{\text {ns }}$ & $-10.00^{(-)}$ & $-8.25^{(-)}$ & $-5.00^{\text {ns }}$ & $-34.75^{(-)}$ & $-19.00^{(-)}$ & $-25.00^{(-)}$ \\
$24-4.0$ & $+2.25^{\text {ns }}$ & $+7.00^{\text {ns }}$ & $+3.00^{\text {ns }}$ & $+6.00^{\text {ns }}$ & $-12.25^{(-)}$ & $-3.25^{\text {ns }}$ & $-0.75^{\text {ns }}$ \\
$48-0.1$ & $-61.00^{(-)}$ & $-51.25^{(-)}$ & $-65.75^{(-)}$ & $-55.50^{(-)}$ & $-65.75^{(-)}$ & $-57.00^{(-)}$ & $-60.00^{(-)}$ \\
$48-0.5$ & $-61.25^{(-)}$ & $-41.50^{(-)}$ & $-63.25^{(-)}$ & $-54.50^{(-)}$ & $-64.25^{(-)}$ & $-50.00^{(-)}$ & $-59.50^{(-)}$ \\
$48-1.0$ & $-28.50^{(-)}$ & $-14.75^{(-)}$ & $-48.25^{(-)}$ & $-35.00^{(-)}$ & $-62.00^{(-)}$ & $-43.00^{(-)}$ & $-39.50^{(-)}$ \\
$48-2.0$ & $-2.75^{\text {ns }}$ & $-15.25^{(-)}$ & $-11.25^{(-)}$ & $-10.00^{(-)}$ & $-40.50^{(-)}$ & $-18.75^{(-)}$ & $-38.25^{(-)}$ \\
$48-4.0$ & $-1.75^{\text {ns }}$ & $+6.50^{\text {ns }}$ & $-10.00^{(-)}$ & $-2.50^{\text {ns }}$ & $-36.50^{(-)}$ & $-8.00^{(-)}$ & $-18.25^{(-)}$ \\
\hline Fungicide & & & & 75 & & & \\
\hline CV $(\%)$ & 5.6 & 5.8 & 6.9 & 5.4 & 9.3 & 4.8 & 5.3 \\
\hline
\end{tabular}

$\mathrm{CV}(\%)=$ coefficient of variation.

${ }^{1}=$ Average differences of the essential oils with the fungicide.

Averages followed by ${ }^{(-)}$or ${ }^{(+)}$in the column were lower or higher, respectively, to the fungicide, at a $1 \%$ probability level by the Dunnett test;

${ }^{n s}=$ averages do not differ from the fungicide at the $1 \%$ probability level by the Dunnett test.

(E. globulus= Eucalyptus globulus; W. thyme= White thyme). 
TABLE 5- Differences between the average percentage of germination inhibition (PGI) of Plasmopara viticola spores, by essential oils and the Manconzeb + metalaxyl-M fungicide, after two incubation periods ( 24 and 48 hours) when the essential oils and the fungicide were applied on grapevine leaves, under field condition. Ilha Solteira, SP, 2013.

\begin{tabular}{|c|c|c|c|}
\hline \multirow{2}{*}{ Essential Oils } & \multicolumn{2}{|c|}{ Incubation Period (h) } & \multirow{2}{*}{ CV $(\%)$} \\
\hline & 24 & 48 & \\
\hline Cinnamon & $-3.00^{\text {ns' }^{1}}$ & $-11.50^{(-)}$ & 2.9 \\
\hline E. globulus & $-11.25^{(-)}$ & $-14.50^{(-)}$ & 4.8 \\
\hline Marjoram & $-25.00^{(-)}$ & $-32.75^{(-)}$ & 5.4 \\
\hline Melaleuca & $-53.00^{(-)}$ & $-61.25^{(-)}$ & 15.4 \\
\hline Peppermint & $-51.25^{(-)}$ & $-60.00^{(-)}$ & 14.9 \\
\hline Oregano & $-3.00^{\mathrm{ns}}$ & $-31.00^{(-)}$ & 3.7 \\
\hline White thyme & $-25.75^{(-)}$ & $-47.50^{(-)}$ & 8.0 \\
\hline Fungicide & & & \\
\hline
\end{tabular}

$\mathrm{CV}(\%)=$ coefficient of variation

${ }^{1}=$ Average differences of the essential oils with the fungicide.

Averages followed by ${ }^{(-)}$or $^{(+)}$in the column were lower or higher, respectively, to the fungicide, at a $1 \%$ probability level by the Dunnett test;

$\mathrm{ns}=$ averages do not differ from the fungicide at the $1 \%$ probability level by the Dunnett test.

(E. globulus= Eucalyptus globulus).

\section{CONCLUSIONS}

In direct contact with the pathogen, the cinnamon essential oil provided greater inhibition of spore germination after $48 \mathrm{~h}$ of incubation.

In gas contact, the major antifungal activity was exhibited by the essential oil of eucalyptus globulus.

The cinnamon and eucalyptus globulus essential oils were more efficient in inhibiting the $P$. viticola germination, after the application in grapevine leaves, in the field.

In the shortest incubation periods, but at high concentrations, the essential oils are as efficient as the fungicide.

The evaluation of $P$. viticola spore germination after several incubation periods, allowed observing the fungistatic activity of the essential oils.

All the essential oils showed fungistatic activity, verified by the increase of the $P$. viticola spores germination over time.

\section{ACKNOWLEDGEMENTS}

We thank to the Foundation for Research Support of the State of São Paulo - Fapesp for the research scholarship for this study and the National Council for Scientific and Technological Development - CNPq for the scholarship to the third and fourth authors.

\section{REFERENCES}

AGROFIT. Sistema de agrotóxicos fitossanitários. Brasília (DF): Ministério da Agricultura, Pecuária e Abastecimento. Disponível em: $\leq$ http://www. agricultura.gov.br> Acesso em: 27 fev. 2015.

AZIZ, A.; TROTEL-AZIZ, P.; DHUICQ, L.; JEANDET, P.; COUDERCHET, M.; VERNET, G. Chitosan oligomers and copper sulfate induce grapevine defense reactions and resistance to gray mold and downy mildew. Phytopathology, Minneapolis, v. 96, n. 11, p.1188-94, 2006.

BANIHASHEMI, Z.; ABIVARDI, C. Evaluation of fungicidal and fungistatic activity of plant essential oils towards plant pathogenic and saprophytic fungi. Phytopathologia Mediterrenea, Firenze, v. 50, n. 2, p. 245-56, 2011.

CHAGAS, H.A.; BASSETO, M.A.; ROSA, D.D.; TOPPA, E.V.B.; FURTADO, E.L.; ZANOTTO, M.D. Avaliação de fungicidas, óleos essenciais e agentes biológicos no controle de Amphobotrys ricini em mamoneira (Ricinus communis L.). Summa Phytopathologica, Botucatu, v.40, n.1, p.42-8, 2014. 
CHANG, S.T.; CHEN, P.F.; CHANG, S.C. Antibacterial activity of leaf essential oils and their constituents from Cinnamomum osmophloeum. Journal of Ethnopharmacology, New York, v.77, n.1, p.123-7, 2001.

FIALHO, R.O. Atividade antifúngica de óleos essenciais sobre os agentes causais do míldio, oídio e ferrugem da videira (Vitis spp.). $2012.62 \mathrm{f}$. Monografia (Trabalho de Graduação em Agronomia) - Faculdade de Engenharia, Universidade Estadual Paulista, Campus de Ilha Solteira, 2012.

FRASSON, D.B.; ARAUJO, D.V.; MACHADO, E.Z.; MAINARDI, J.T.; MENIN, L.F.; MIRANDA, E.L. Avaliação a campo da transmissibilidade de Fusarium oxysporum f.sp.vasinfectum inoculado em sementes de algodoeiro. Tropical Plant Pathology, Brasília, DF, v.35, p.S127, 2010.

GARRIDO, L.R.; ANGELOTTI, F. Impacto potencial das mudanças climáticas sobre as doenças da videira no Brasil. In: GHINI, R., HAMADA, E.; BETTIOL, W. (Ed.). Impactos das mudanças climáticas sobre doenças de importantes culturas no Brasil. Jaguariúna: Embrapa Meio Ambiente, 2011. p.331-56.

IBGE - Instituto Brasileiro de Geografia e Estatística. Pesquisa mensal de previsão e acompanhamento das safras agrícolas no ano civil. Levantamento sistemático de Produção Agrícola, Rio de Janeiro, v.27 n.21, p.1-85, 2014.

KALEMBA, D.; KUNICKA, A. Antibacterial and antifungal properties of essential oils. Current Medicinal Chemistry, Hilversum, v.10, n.10, p.81329, 2003.

KISHORE, G.K.; PANDE, S.; HARISH, S. valuation of essential oils and their components for broadspectrum antifungal activity and control of late leaf spot and crown rot diseases in peanut. Plant Disease, Minneapolis, v.91, n.4, p.375-9, 2007.

KOKETSU, M.; GONÇALVES, S.L.; GODOY, R.; LOPES, L.O.; DAISE, L.; MORSBACH, N. Óleos essenciais de cascas e folhas de canela (Cinnamomum verum Presl) cultivada no Paraná. Ciências e Tecnologia de Alimentos, Campinas, v.17, n.3, p.281-5, 1997.
LEITE, C.D.; BOTELHO, R.V.; FARIA, C.M.D.R.; MAIA, A.J.Extrato de alho e óleo vegetal no controle do míldio da videira. Revista Brasileira de Fruticultura, Jaboticabal, v.33, n.2, p.429-36, 2011.

LORENZETTI, E.R.; CONCEICAO, D.M.; SACRAMENTO, L.V.S.; FURTADO, E.L. Controle da ferrugem das folhas do capim-limão [Cymbopogon citratus (DC:) Stapf] com produtos naturais. Revista Brasileira de Plantas Medicinais, Botucatu, v.14, n.4, p.571-8, 2012.

LUCAS, G.C. Óleos essenciais no controle da pinta preta do tomateiro. 2012. $92 \mathrm{f}$. Tese (Doutorado em Fitopatologia) - Universidade Federal de Lavras, Lavras, 2012.

MAIA, J.A.; SCHWAN-ESTRADA, K.R.F.; FARIA, C.M.D.R.; OLIVEIRA, J.S.B.; JARDINETTI, V.A.; BATISTA, B.N.B. Óleo essencial de alecrim no controle de doenças e na indução de resistência. Pesquisa Agropecuária Brasileira, Brasília, DF, v.49, n.5, p.330-9, 2014.

MALLET, A.C.T.; CARDOSO, M.G.; SOUZA, P.E.; MACHADO, S.M.F.; ANDRADE, M.A.; NELSON, D.L.; PICCOLI, R.H.; PEREIRA, C.G. Chemical characterization of the Allium sativum and Origanum vulgare essential oils and their inhibition effect on the growth of some food pathogens. Revista Brasileira de Plantas Medicinais, Botucatu, v.16, n.4, p.804-11, 2014.

MAQBOOL, M.; ALI, A.; ALDERSON, P.G. Effect of cinnamon oil on incidence of anthracnose disease and postharvest quality of bananas during storage. International Journal of Agriculture and Biology, Faisalabad, v.12, n.4, p.516-20, 2010.

MORAIS, L.A.S. Influência dos fatores abióticos na composição química dos óleos essenciais. Horticultura Brasileira, Brasília, DF, v.27, n.2, p.4050-63, 2009.

NAVES, R.L.; GARRIDO, L.R.; SÔNEGO, O.R. Controle de doenças fúngicas em uvas de mesa na região Noroeste do Estado de São Paulo. Bento Gonçalves: Embrapa Uva e Vinho, 2006. 17 p. (Circular Técnica, 68). 
OLADIMEJI, F.A.; ORAFIDIYA, O.O.; OKEKE, I.N.; DAGNE, E. Effect of autoxidation on the composition and antimicrobial activity of essential oil of Lippia multiflora. Pharmaceutical and Pharmacological Letters, Stuttgart, v.11, n.2, p.647,2001.

OOTANI, M.A. Atividade inseticida, antifúngica e herbitóxica dos óleos essenciais de Eucalyiptus citriodora e Cymbopogon nardus. 2010. 122f. Dissertação (Mestrado em Produção Vegetal) Campus Universitário de Gurupi, Universidade Federal do Tocantins, Gurupi, 2010.

PERINA, F.J.; AMARAL, D.C.; FERNANDES, R.S.; LABORY, C.R.; TEIXEIRA, G.A.; ALVES, E. Thymus vulgaris essential oil and thymol against Alternaria alternata (Fr.) Keissler: effects on growth, viability, early infection and cellular mode of action. Pest Management Science, London, v.71, n.10, p.1371-8, 2015.

PIATTI, A.; SCHNEIDER, C.F.; NOZAKI, M.H. Efeito in vitro do óleo essencial de Eucalyptus globulus sobre o crescimento e desenvolvimento de Penicillium sp. Semina: Ciências Agrárias, Londrina, v.32, n.3, p.1033-40, 2011.

R DEVELOPMENT CORE TEAM. R: a language and environment for statistical computing. Vienna: R Foundation for Statics Computing, 2011. Disponível em: <http://www.R-project.org/>. Acesso em: 10 jun. 2015.

RANASINGHE, L.; JAYAWARDENA, B.; ABEYWICKRAMA, K. Fungicidal activity of essential oils of Cinnamomum zeylanicum (L.) and Syzygium aromaticum (L.) Merr et L.M.Perry against crown rot and anthracnose pathogens isolated from banana. Letters in Applied Microbiology, West Sussex, v.35, n.3, p.208-11, 2002.

SILVA, C.M.; BOTELHO, R.V.; FARIA, C.M.R.D.; STADLER, T.P. Controle alternativo do míldio da videira com extrato aquoso de cinamomo e óleo vegetal. Arquivos do Instituto Biológico, São Paulo, v.79, n.4, p.587-94, 2012.

SILVA, C.R.; BOTELHO, R.V.; FARIA, C.M.D.R. Ação de extratos de cinamomo sobre Plasmopara viticola. Bioscience Journal, Uberlândia, v.30, supl.2, p.639-49, 2014.
SILVA, H.R.; SOUZA, P.E.D.; SILVA, J.L.D.; FREITAS, M.L.O. Potencial de óleos essenciais no manejo da cercosporiose em plantas de café. Tropical Plant Pathology, Brasília, DF, v.38, p.632, 2013.

SIMÕES, C.M.O.; SPITZER V. Óleos voláteis. In: SIMÕES, C.M.O.; SCHENKEL, E.P.; GOSMANN, G.; MELLO, J.C.P.; MENTZ, L.A.; PETROVICK, P.R. (Org.). Farmacognosia: da planta ao medicamento. 5.ed. Porto Alegre: UFRGS/UFSC, 2004. p.467-95.

SOUZA, E.L.; STAMFORD, T.L.M.; LIMA, E.O.; TRAJANO, V.N.; FILHO, J.M.B.Antimicrobial effectiveness of spices: an approach for use in food conservation systems. Brazilian Archives of Biology and Technology, Curitiba, v.48, n.4, p.549-58, 2005.

TRIPATHI, P.; DUBEY, N.K.; SHUKLA, A. Use of some essential oils as post-harvest botanical fungicides in the management of grey mold of grapes caused by Botrytis cinerea. World Journal of Microbiology and Biotechnology, Oxford, v.24, n.1, p.39-46, 2008.

VILELA, G.R.; ALMEIDA, G.S.; D'ARCE, M.A.B.R.; MORAES, M.H.D.; BRITO, J.O.; SILVA, M.F.G.F.; SILVA, S.C.; PIEDADE, S.M.S.; CALORI-DOMINGUES, M.A.; GLORIA, E.M. Activity of essential oil and its major compound, 1,8-cineole, from Eucalyptus globulus Labill., against the storage fungi Aspergillus flavus Link and Aspergillus parasiticus Speare. Journal of Stored Products Research, Oxford, v.45, n.2, p.108-11, 2009.

VITURRO, C.I.; MOLINA, A.C.; HEIT, C.I. Volatile components of Eucalyptus globulus Labill ssp.bicostata from Jujuy. Journal of Essential Oil Research, New York, v.15, n.3, p.206-8, 2003. 